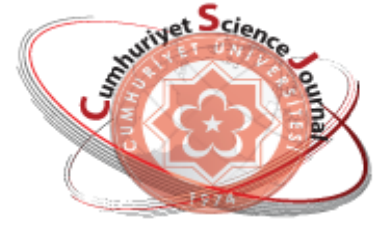

e-ISSN: $2587-246 X$

ISSN: $2587-2680$

\section{Cumburiy ot Seioneajournal}

esJ

Cumhuriyet Sci. J., Vol.39-2(2018) 469-476

\title{
The Investigation of Ni (II) Removal by Biocomposite Synthesized with the Immobilization of Candida Utilis on Chitosan
}

\author{
Feray KIP*, Unsal ACIKEL \\ Cumhuriyet University, Department of Chemical Engineering, Sivas, TURKEY
}

Received: 11.04.2017; Accepted: 24.04.2018

http://dx.doi.org/10.17776/csj.434258

\begin{abstract}
In this study, $\mathrm{Ni}(\mathrm{II})$ adsorption was examined with the biocomposite prepared with the immobilization of Candida utilis on chitosan polymer. The FTIR and SEM analyses of chitosan-Candida utilis biocomposite were carried out before and after adsorption of $\mathrm{Ni}$ (II) ions. For the $\mathrm{Ni}(\mathrm{II})$ adsorption by $C$. utilis immobilized on chitosan, the $\mathrm{Ni}$ (II) concentrations were changed in the concentration range of 10-100 $\mathrm{mg} / \mathrm{L}$. For the $\mathrm{Ni}(\mathrm{II})$ adsorption by $C$. utilis immobilized on chitosan, the optimum $\mathrm{pH}$ value was determined to be 4.0, and temperature was determined to be $25{ }^{\circ} \mathrm{C}$. Under these experimental conditions, the maximum adsorbed amount of $\mathrm{Ni}$ (II) per unit weight of adsorbent was found to be $9.5 \mathrm{mg} / \mathrm{g}$. The adsorption equilibrium data adjusted to the Langmuir isotherm model. The kinetic data were represented by the pseudo-first-order kinetic model. The enthalpy, entropy and Gibbs free energy changes were found to be $-4.61 \mathrm{kj} / \mathrm{mol}, 1.97$ $\mathrm{j} / \mathrm{mol},-10.48 \mathrm{kj} / \mathrm{mol}$, respectively. With respect to the results obtained in this study, new chitosan-Candida utilis biocomposites will become an alternative for the removal of heavy metals from wastewaters.
\end{abstract}

Keywords: Wastewater, chitosan, Candida utilis, Ni(II), adsorption.

\section{Candida Utilis ’in Kitosana Tutuklanması ile Sentezlenen Biyokompozit ile $\mathrm{Ni}$ (II) Gideriminin İncelenmesi}

\begin{abstract}
Özet: Bu çalışmada, kitosan polimeri üzerine Candida utilis'in tutuklanması ile hazırlanan biyokompozit ile $\mathrm{Ni}$ (II) adsorpsiyonu incelenmiştir. Kitosan-Candida utilis biyokompozitinin FTIR ve SEM analizleri Ni (II) iyonlarının adsorpsiyonundan önce ve sonra gerçekleştirildi. Kitosan üzerine tutuklanan C.utilis'in Ni (II) adsorpsiyonunda, Ni (II) konsantrasyonları 10-100 mg / L konsantrasyon aralığında değiştirilmiştir. Kitosan üzerine C.utilis'in Ni (II) adsorpsiyonu için ile elde edilen optimum pH değerinin 4.0 ve sıcaklık değerlerinin $25^{\circ} \mathrm{C}$ olduğu belirlenmiştir. Bu deney koşulları altında, adsorbanın maksimum adsorbe edilmiş Ni (II) miktar1 $9.5 \mathrm{mg} / \mathrm{g}$ olarak bulunmuştur. Adsorpsiyon denge verileri Langmuir izoterm modeline uygun olduğu belirlenmiştir. Kinetik veriler, yalancı birinci dereceden kinetik modeline uygun olduğu tespit edilmiştir. Entalpi, entropi ve Gibbs serbest enerji değişimleri sırasıyla $-4.61 \mathrm{kj} / \mathrm{mol}, 1.97 \mathrm{j} / \mathrm{mol},-10.48 \mathrm{kj} / \mathrm{mol}$ olarak bulunmuştur. Bu çalışmada elde edilen sonuçlarla ilgili olarak, yeni chitosan-Candida utilis biyokompozitinin kullanımı, atıksularki ağır metallerin uzaklaştırılmasında bir alternatif haline gelecektir.
\end{abstract}

AnahtarKelimeler: Atıksu, kitosan, Candida utilis, Ni(II), adsorpsiyon.

\section{INTRODUCTION}

The presence of heavy metals in wastewater damages human health and it causes health problems in the food chain with its accumulation in living tissues, which has become an important issue in recent years [1]. In addition to classical chemical and physical methods used in the removal of heavy metals, the performances of non-living microorganisms have drawn attention recently due to cost

\footnotetext{
* Corresponding author. Email address: feray.kip@gmail.com

http://dergipark.gov.tr/csj @2016 Faculty of Science, Cumhuriyet University
} 
effectiveness and their being environmentfriendly sorbents [2]. Bacteria such as Bacillus cereus, Escherichia coli, etc. and fungal adsorbents such as Aspergillus niger, Rhizopusarrhizus, etc. which are used for the biosorption of heavy metals from aqueous solutions are easily-reproducing biomasses and can also be modified on support [3]. Lijida et al. (2015) examined the immobilization of candida rugose lipase on silica SBA-15 and zirconia support [4]. The immobilization which begins with the cell's adsorption to solid surface overcomes the van der Waals forces and electrostatic driving forces [5] after a certain period of time and attaches to the solid surface with the hydrophobic interaction, polar interaction, hydrogen bonds and the interaction of various specific molecules [6]. In their study, Monvisade and Siriphannon (2009), by using this method, added clay (montmorillonite) to chitosan and examined the adsorption of the prepared composite (Chitosan-MMT) in cationic dyes. They are immobilizedbiocomposite materials, which are an alternative method used for the removal of heavy metals from high concentrated solutions or wastewater [7]. In this study, the adsorption of the biocomposite materials prepared with chitosan and Candida utiliswas examined for $\mathrm{Ni}$ (II) ions and it is considered to become an alternative for the treatment of the waters with the high heavy metal pollution.

\section{MATERIALS and METHOD}

\subsection{Reagents}

The chemicals used in the experiments are of Sigma-Aldrich brand, and Candida utilisis $A T C C{ }^{\circledR} 9950^{\mathrm{TM}}$ ferment strains obtained from Ankara University, Department of Biology.

\subsection{Immobilization of Candida utilis on chitosan}

$1 \mathrm{~g}$ of chitosan was added to $3 \mathrm{~g}$ of wet Candida utilis and they were mixed under room conditions. The samples were kept at room temperature for 12 hours and the batch system experiments were performed.

\subsection{Batch Reactor Experiments}

The optimum reproduction conditions of Candida utilis were determined to be $25{ }^{\circ} \mathrm{C}$ and $\mathrm{pH}$ 4. Candida utilis was left for reproduction at $95 \mathrm{rpm}$ mixing speed for 4 days. Candida utilis obtained afterwards was centrifuged and stored in the fridge. The adsorbents used in the experiment are chitosan and the biocomposite material formed with the adsorption of Candida utilis on chitosan. Experimental studies were examined in the batch system. Afterwards, a specific amount was taken from the samples and centrifuged and the adsorption values were measured by using the UV spectrometer at 460 $\mathrm{nm}$. The adsorption of $\mathrm{Ni}$ (II) solutions prepared in $10-100 \mathrm{mg} / \mathrm{L}$ concentration was examined for 10-240 minutes. The maximum adsorption effect of $\mathrm{Ni}(\mathrm{II})$ solutions in $100 \mathrm{mg} / \mathrm{L}$ concentration between $25-55^{\circ} \mathrm{C}$ was measured to determine thermodynamic parameters and the adsorption amount was calculated (Equation 1) $[8]$.

$q_{e}=\frac{(\mathrm{Co}-\mathrm{Ce}) \mathrm{V}}{m}$

\subsection{Adsorption Isotherms}

The dispersion of metal ions between the liquid and solid phase in adsorption processes can be explained by the Langmuir isotherm model (Equation 2) and Freundlich isotherm model (Equation 3) [9].

$$
\begin{aligned}
& q_{e}=\frac{Q_{\max } a_{L} C_{e}}{1+a_{L} C_{e}} \\
& q_{e}=K_{F} C_{e}^{\frac{1}{n}}
\end{aligned}
$$

\subsection{Adsorption Kinetics}

The equations used to determine adsorption kinetics are as follows.

The pseudo-first-order kinetic model: 
$\log \frac{\left(q_{e}-q\right)}{q_{e}}=-\frac{k_{1, a d} t}{2.303}$

The pseudo-second-order kinetic model is expressed as follows and given with the following formula [10]:

$\frac{t}{q t}=\frac{1}{k_{2} q_{e}^{2}}+\frac{t}{q_{e}}$

\subsection{Adsorption Thermodynamics}

The thermodynamic parameters of enthalpy, entropy and free energy change for the adsorption process are given in Equation 6 [11].

$\Delta G^{0}=\Delta H^{0}-T \Delta S^{0}$

\section{RESULTS and DISCUSSION}

\subsection{Adsorption Kinetics}

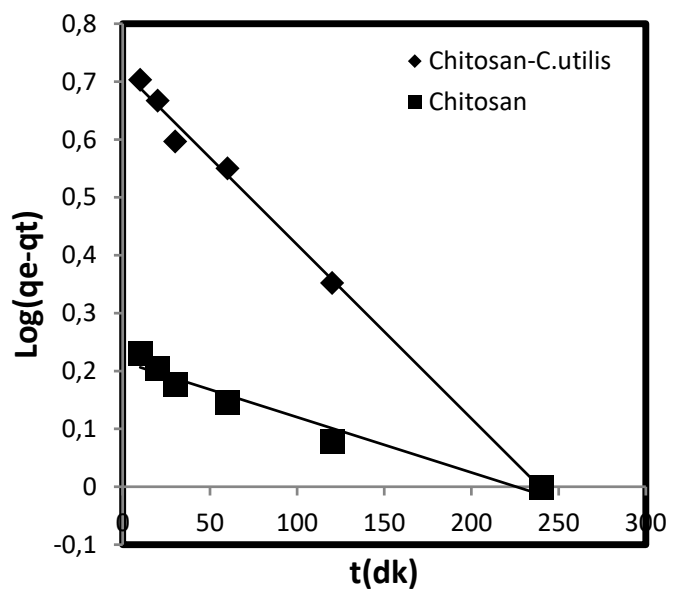

(a)

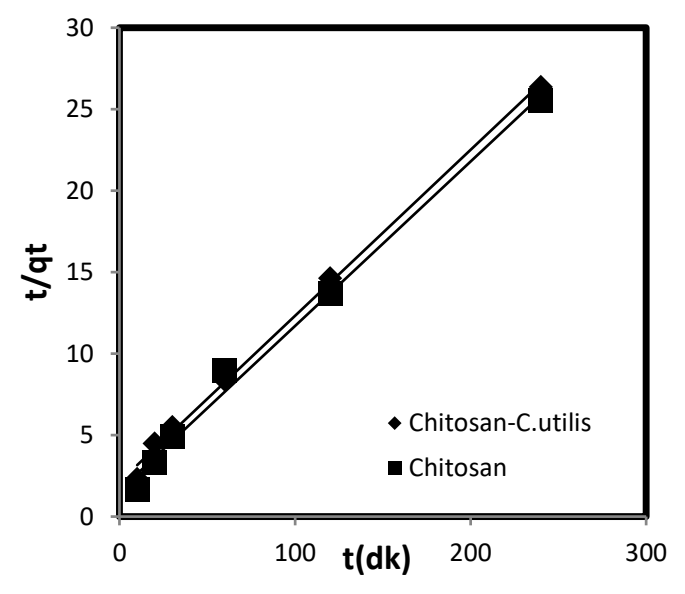

(b)

Figure 1-(a). Pseudo-first-order kinetic model (b).Pseudo-second-order kinetic model for the Ni (II) adsorption of adsorbents.

Table 1. Pseudo-first and second-order kinetic model parameters for Ni (II) adsorption.

\begin{tabular}{lll|ccc|ccc}
\hline \multirow{2}{*}{$25^{0} \mathrm{C}$} & \multicolumn{3}{c|}{ Experimental Data } & \multicolumn{3}{c|}{ Pseudo first-order kinetic model } & \multicolumn{3}{c}{ Pseudo second-order kinetic model } \\
& $\mathrm{Ce}\left(\mathrm{mgL}^{-1}\right)$ & $\mathrm{qe}\left(\mathrm{mgg}^{-1}\right)$ & $\mathrm{qe}\left(\mathrm{mg} \mathrm{g}^{-1}\right)$ & $\mathrm{k}_{1}\left(\mathrm{dk}^{-1}\right)$ & $\mathrm{R}^{2}$ & $\mathrm{qe}(\mathrm{mg} / \mathrm{g})$ & $\mathrm{k}_{2}\left(\mathrm{~g} \mathrm{mg}^{-1} \mathrm{dk}^{-1}\right)$ & $\mathrm{R}^{2}$ \\
\hline PAN-C.utl & 38.5 & 9.51 & 5.22 & 0.0069 & 0.995 & 9.52 & 0.0031 & 0.997 \\
PAN & 55.1 & 7.15 & 1.65 & 0.0023 & 0.957 & 7.25 & 0.0045 & 0.992 \\
\hline
\end{tabular}

\subsection{Adsorption Isotherms}

$\mathrm{R}^{2}$ values determine the isotherm type and if $\mathrm{R}>1$, it signifies that it is unfavorable for adsorption, if $0<\mathrm{R}<1$, it signifies that the
The contact time for $\mathrm{Ni}$ (II) adsorption was examined in the stationary initial $\mathrm{Ni}$ (II) concentration for chitosan and chitosanCandida utilisbiocomposite. Although $\mathrm{Ni}(\mathrm{II})$ adsorption was rapid at the beginning, it decelerated over time. This decrease showed that the adsorption on the surface was singlelayered [12]. When Log (qe-qt) versus $t$ is displayed in a graph, figure 1-a line is obtained; and when t/qt versus $t$ is displayed in a graph, figure 1-b line is obtained. When the experimental qe and correlation values were examined, the biocomposites were observed to be compatible with the pseudo-first-order kinetic model. The constants for the adsorption kinetic model are presented in Table 1 for 100 $\mathrm{mg} / \mathrm{L} \mathrm{Ni}$ (II) concentration. 
Langmuir isotherm model (Figure 2-a) for $\mathrm{Ni}$ (II). This situation can be explained by the fact that the biocomposite surface has homogeneous structure and by the presence of bonding regions that will enable single-layered adsorption [14].

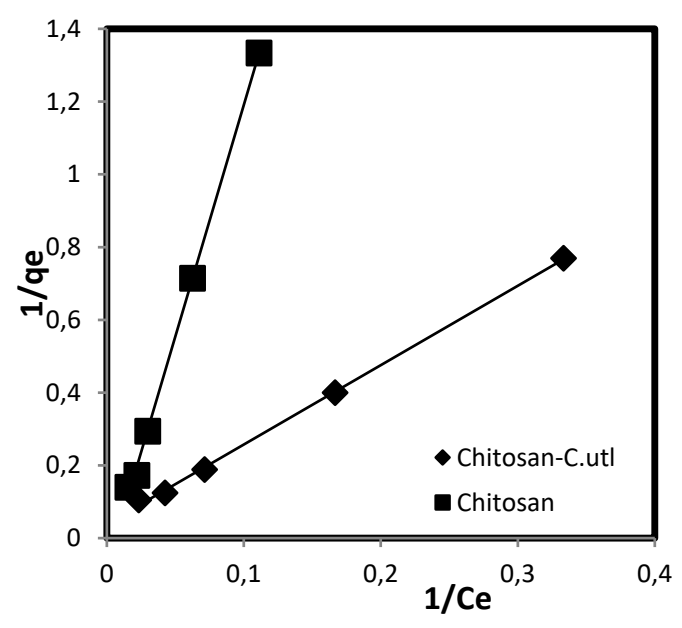

(a)
Chitosan-Candida utilis showed a higher removal for $\mathrm{Ni}$ (II) only in comparison with chitosan (Table 2). This situation realizes with $\mathrm{Ni}$ (II) ion's adsorption on the sorption regions on the adsorbent surface with the electrostatic interaction of metal ions in the microenvironment [15].

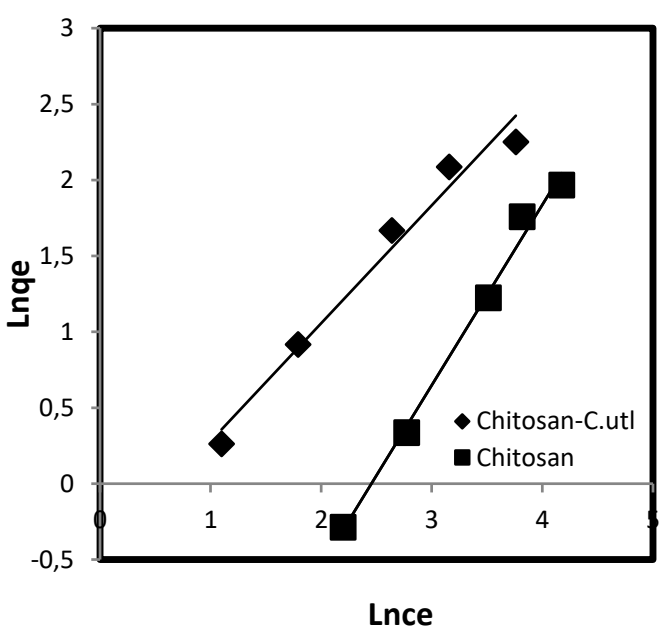

(b)

Figure 2-(a) Langmuir isotherm (1/Qe- 1/Ce) (b)Freundlich isotherm (InQe- InCe) graph.

Table 2. Langmuir and Freundlich isotherm model of Ni(II) chitosan and chitosan-Candida utilisbiocomposite.

\begin{tabular}{lccc|cccr}
\hline & \multicolumn{3}{c}{ Langmuir } & \multicolumn{4}{c}{ Freundlich } \\
\hline & $\mathrm{Q}_{\mathrm{e}}(\mathrm{mg} / \mathrm{g})$ & $\mathrm{b}$ & $\mathrm{R}^{2}$ & $\mathrm{~K}_{\mathrm{f}}$ & $\mathrm{n}_{\mathrm{f}}$ & $\mathrm{R}^{2}$ \\
\hline PAN-C.utl & 26.31 & 0.0608 & 0.999 & 2.6 & 1.83 & 0.980 & \\
PAN & 22.5 & 0.0054 & 0.998 & 2.1 & 1.18 & 0.987 & \\
\hline
\end{tabular}

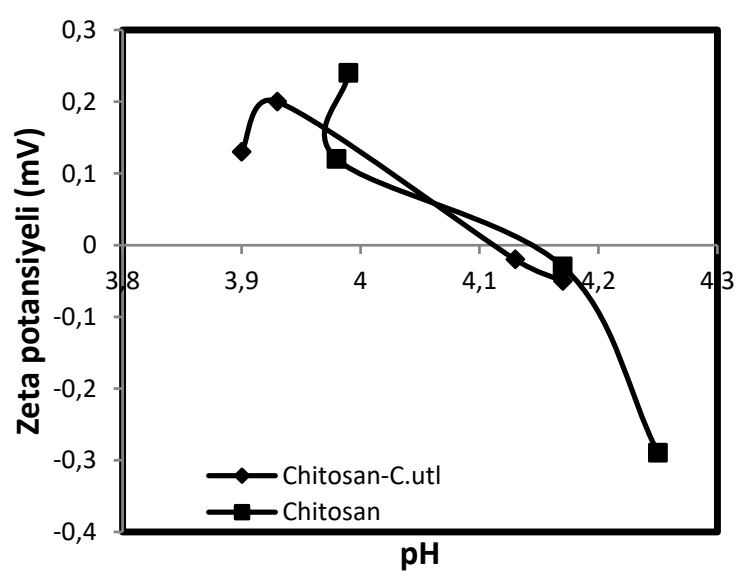

Figure 3. The pH-zeta potential relation of chitosan and chitosan-Candida utilisbiocomposite for $\mathrm{Ni}(\mathrm{II})$.

Candida utilis plays an important role in reproducing in the environments with acidic $\mathrm{pH}$ and heavy metal contamination, in adjusting the ambient $\mathrm{pH}$ and conducting experimental studies. When the $\mathrm{pH}$ range is examined, it is observed that as $\mathrm{pH}$ increases, the removal of $\mathrm{Ni}$ (II) ions decreases in the range between 3.85 and 4.3 as in figure 3 because with the increase in $\mathrm{pH}, \mathrm{H}^{+}$ions which decrease in the environment reduce the electrostatic interaction between $\mathrm{Ni}$ (II) ions and the composite surface. This is becausethepH of $\mathrm{Ni}$ (II) solution is relatedtothecondition of functionalgroups on thebiocompositesurfaceanddifferentresultsareob tainedforbiocomposite. Themobility of $\mathrm{H}^{+}$ion at lowpH is higherwhencomparedtoNi (II) ion. Thisdecreasestheadsorption of $\mathrm{Ni}$ (II). IfthepH of thesolutionincreases, $\mathrm{Ni}$ (II) ionwill be adsorbedmoretothesolidsurface since therewill be less $\mathrm{H}^{+}$ion in theenvironment. $\mathrm{pH}$ is one of 
theimportantfactorsaffectingadsorptionfordiffer entbiocompositematerials. ThepH of thesolution has an effect on metalbindingregions of thebiocompositesurfaceandchangesthephysicoc hemicalcharacteristics of the metal [16].

\subsection{Thermodynamic Parameters}

The change of the Gibbs free energy, enthalpy and entropy equilibrium constant with temperature was calculated with the $\Delta \mathrm{G}$ versus $\mathrm{T}$ graph as seen in figure 4 . The fact that $\Delta \mathrm{G}<0$ originates from the fact that the concentration around the biocomposite is higher when compared to the concentration within the biocomposite. The negative $\Delta \mathrm{G}$ values indicate that $\mathrm{Ni}$ (II) isadsorped spontaneously. The positive $\Delta S$ value originates from the increase in randomness and affinity on the solid-liquid interface during adsorption. The negative $\Delta \mathrm{H}$ value (Table 3) in this spontaneous event due to the equilibrium condition showed that the interaction on the surface was exothermic [17].

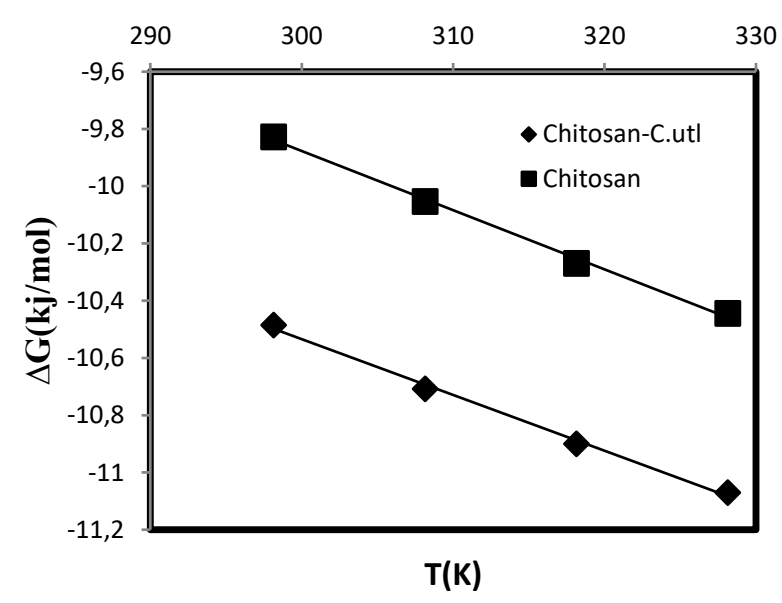

Figure 4. The change of the Gibbs free energy with temperature for $\mathrm{Ni}(\mathrm{II})$.

Table 3. Thermodynamic parameters for Ni(II) adsorption.

\begin{tabular}{lcccccc}
\hline & \multicolumn{2}{c}{$\Delta \mathrm{G}(\mathrm{kj} / \mathrm{mol})$} & \multicolumn{2}{c}{$\mathrm{T} \Delta \mathrm{S}(\mathrm{kj} / \mathrm{mol})$} & \multicolumn{2}{c}{$\Delta \mathrm{H}(\mathrm{kj} / \mathrm{mol})$} \\
\hline $\mathrm{T}(\mathrm{K})$ & chitosan+C.utilis & chitosan & chitosan+C.utilis & chitosan & chitosan+C.utilis & chitosan \\
\hline 298.15 & -10.48 & -9.82 & 5.88 & 6.21 & -4.61 & -3.71 \\
308.15 & -10.71 & -10.05 & 6.08 & 6.33 & & \\
318.15 & -10.01 & -10.26 & 6.28 & 6.54 & & \\
328.15 & -11.07 & -11.07 & 6.48 & 6.74 & & \\
\hline
\end{tabular}

In this study, the adsorption skills of Candida utilis on their own increased the adsorption capacity of a newly-developed biocomposite material.

\subsection{FTIR and SEM Analyzes}

\subsubsection{FTIR}

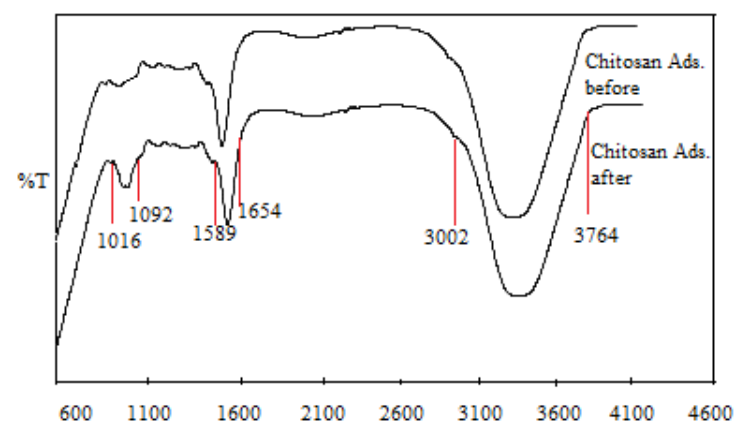

(a)

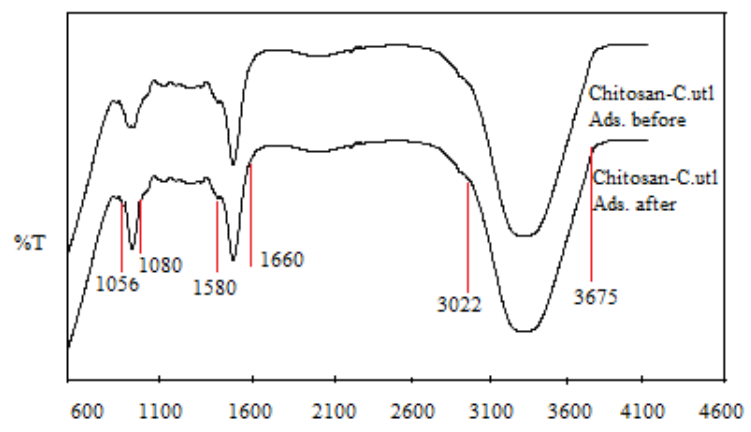

(b)

Figure 5. Pre- and post-adsorption of (a) chitosan (b) chitosan-Candida utilisbiocomposite. 
When the FTIR spectrum was examined, it was observed that the peak severity observed after adsorption for chitosan (figure 5-a) and chitosan-Candida utilisbiocomposite (figure 5b) was higher in comparison to the peak severity observed before adsorption. It was considered that the wide peak range at 3022$3675 \mathrm{~cm}^{-1}$ wavelength belonged to the hydroxyl bond (-OH) of chitosan, the peak at 1580-1660 $\mathrm{cm}^{-1}$ wavelength belonged to amide $\mathrm{N}-\mathrm{H}$ bending peak, the peak at 1056- $1080 \mathrm{~cm}^{-1}$ wavelength belonged to the asymmetrical bending peak of $\mathrm{CH}_{2}$ for chitosan-Candida utilis before adsorption (figure 5-b) [18]. It was observed that after adsorption, chitosanCandida utilisbiocomposite had a higher peak severity in comparison to chitosan. This situation originates from the fact that the multifunctional group interacts with $\mathrm{Ni}$ (II) ions with the adsorption process and can be explained by the fact that the functional groups in the structure of Candida utilis have a higher affinity for Ni (II) ions [19].

\subsubsection{SEM}

The pre-adsorption and post-adsorption SEM images are presented in figure 6 for chitosanCandida utilisbiocomposite. It was observed that chitosan-Candida utilisbiocomposite had a porous structure before adsorption. It was considered that the surface area of chitosanCandida utilisbiocomposite, which increased with the pore size after adsorption, was completely filled with $\mathrm{Ni}$ (II) ions [20].

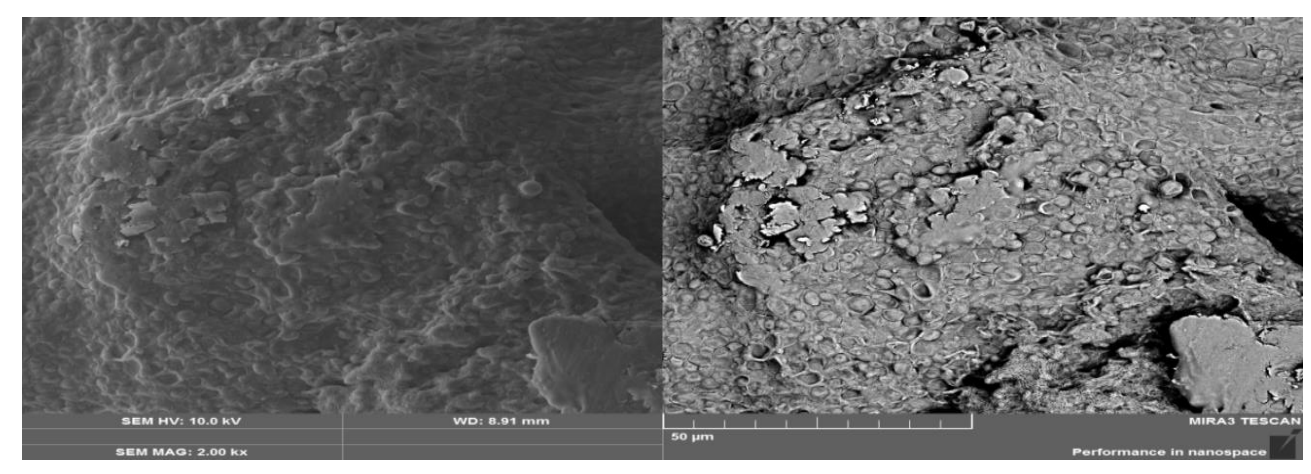

(a)

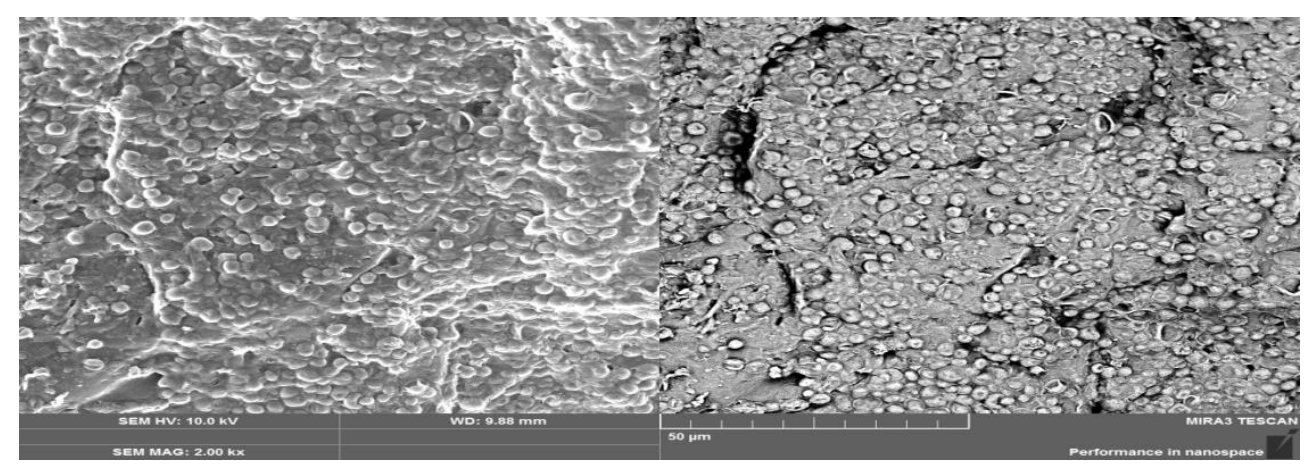

(b)

Figure 6. Chitosan-Candida utilisbiocomposite (a) before adsorption (b) after adsorption.

\section{CONCLUSION}

In this study, Ni (II) adsorption was examined with the biocomposite material prepared with chitosan and Candida utilis. The adsorption skills of Candida utilis on their own increased the adsorption capacity of a newly-developed biocomposite material. The experimental data were observed to be compatible with the Langmuir isotherm model for chitosan and chitosan-Candida utilisbiocomposite. Kinetic parameters were calculated using the pseudo- 
first and second-order kinetic model under optimum conditions. The Gibbs free energy, enthalpy and entropy equilibrium constant were calculated according to the change with temperature for thermodynamic parameters.As a result of the studies, Ni (II) removalfor chitosan-Candida utilis composite was higher only in comparison to chitosan. It is considered that chitosan-Candida utilisbiocomposite will become an alternative for the removal of heavy metals and this study will become an example study for the production of new biocomposite materials due to a limited number of similar studies in the literature.

\section{SYMBOLS}

$\mathbf{C}_{\mathrm{e}}$ : The concentration of the substance left in the solution after adsorption $(\mathrm{mg} / \mathrm{dm} 3)$

$\mathbf{C}_{\mathbf{a}}$ : The amount of the substance kept in the unit mass of the adsorbent $(\mathrm{mg} / \mathrm{g})$

Qe: The amount of the substance adsorbed on the unit adsorbent $(\mathrm{mg} / \mathrm{g})$

$\mathbf{K}_{\mathbf{F}}$ : Adsorption capacity calculated experimentally

$\mathbf{K}_{\mathbf{c}}$ : Equilibrium constant

k1.ad: First-order rate constant $\left(\mathrm{min}^{-1}\right)$

k2: Second-order rate constant $\left(\mathrm{g} \mathrm{mg}^{-1} \mathrm{~min}^{-1}\right)$

$\mathbf{N}$ : Adsorption degree

aL: Constant dependent on the adsorption energy $\left(\mathrm{dm}^{3} / \mathrm{mg}\right)$

$\Delta \mathbf{G}^{\mathbf{0}}$ : Free energy change $(\mathrm{kJ} / \mathrm{mol})$

$\Delta \mathbf{H}^{\mathbf{0}}:$ Enthalpychange $(\mathrm{kJ} / \mathrm{mol})$

$\Delta \mathbf{S}^{\mathbf{0}} \mathbf{:}$ Entropy change $(\mathrm{kJ} / \mathrm{mol} \mathrm{K})$

T: Absolute temperature (Kelvin)

R: Gas constant $(8.314 \mathrm{~J} / \mathrm{mol} \mathrm{K})$

\section{REFERENCES}

[1]. Suhong C., Qinyan Y., Baoyu G., Qian L., Xing X., Removal of Cr (VI) from aqueous solution using modified corn stalks: Characteristic, equilibrium, kinetic and thermodynamic study, Chemical Engineering Journal, 168 (2011) 909-917.

[2]. Yu, X., Tong S., Ge M., Wu L., Zou J., Cao C., Song W., Adsorption of heavy metal ions from aqueous solution by carboxylated cellulose nanocrystals, Journal of Environmental Sciences, 25-5 (2013) 933-943.

[3]. Chatterjee S.K., Bhattacharjee I.,
Chandra G., Biosorption of heavy metals from industrial waste water by Geobacillus thermode nitrificans, Journal of Hazardous Materials, 175 (2010) 117125.

[4]. Lidija T., Ljiljana S., Biljana M, Maja J., Bojan M., Ivanka M., Immobilization of Candida rugosa lipase by adsorption onto biosafemeso/macroporous silica and zirconia, Biochemical Engineering Journal, 93 (2015) 73-83.

[5]. Jin Y.L., Speers R.A., Flocculation of Saccharomyces cerevisiae, Food Res Int., 31 (1998) 421-440.

[6]. Rapoport A., Borovikova B., Kokina A., Patmalnieks A., Polyak N., Pavlovska I., Mezinskis G., Dekhtyar Y., Immobilisation of yeast cells on the surface of hydroxyapatite, Process Biochemistry, 46 (2011) 665-670.

[7]. Monvisade P., Siriphannon P., Chitosan intercalated montmorillonite: Preparation, characterization and cationic dye adsorption, Applied calay Science, (2009) 427.

[8]. Cheung W.H., Ng. J.C.Y., McKay G., Equilibrium studies for the sorption of lead from effluents using chitosan, Chemosphere, 52 (2003) 1021-1030.

[9]. Aksu Z., Yener J., A comparative adsorption/biosorption study of monochlorinat phenols onto various sorbents, Waste Management, 21 (2001) 695-702.

[10]. Bayat B., Comparative study of adsorption properties of Turkish fly ashes, The case of nickel(II), copper(II) and zinc(II), Journal of Hazardous Materials, 95-3 (2002) 251-273.

[11]. Khesami L., Capart R., Removal of Chromium (VI) from aqueous solutions by activated carbons: kinetic and equilibrium studies, Journal of Hazardous Materials, 123 (2005) 223132.

[12]. Fenglian F., Qi W., Removal of heavy metal ions wastewaters, Journal of Environmental Management, 92 (2011) 407-418. 
[13]. Tünay O., Kabdaşlı I. Fiziksel Kimya,1. Baskı, İ.T.Ü. Yayınları, İstanbul, (1996) 168.

[14]. Van Oss C.J., Chaudhury M.K., Good R.J., Interfacial Lifshitz van der Waals and polar interaction in macroscopic systems, Chem Rev., 88 (1988) 927-941.

[15]. Lu S., Gibss S.W., Copper removal from wastewater using spent grain as biosorben', Bioresource Technology, 77 (2008) 7-17.

[16]. Ertugay N., Bayhan Y.K., Biosorption of $\mathrm{Cr}$ (VI) from aqueous solutions by biomass of Agaricusbisporus, Journal of Hazardous Materials, 154 (2008) 432439.

[17]. Kul A.R., Koyuncu H., Adsorption of Pb (II) ions from aqueous solution by native and activated bentonite: Kinetic, equilibrium and thermodynamic study, Journal of Hazardous Materials, (2010)
332-339.

[18]. Kirtikumar C., Kishor P., Bhalchandra M., Immobilization of Candida cylindracea lipase on poly lactic acid polyvinyl alcohol and chitosan based ternary blend film, Characterization activity stability and its application for N-acylation reactions, Process Biochemistry, 48 (2010) 1335-1347.

[19]. Zhao Y., Tan Y., Guo Y., Gu X., Wang X., Zhang Y., Interactions of tetracycline with $\mathrm{Cd}$ (II), $\mathrm{Cu}$ (II) and $\mathrm{Pb}$ (II) and their cosorption behavior in soils, Environ. Pollut., 180 (2013) 206-213.

[20]. Xiaoli L., Yanfeng L., Zhengfang Y., Preparation and characterization of new foam adsorbents of poly(vinyl alcohol)/chitosan composites and their removal for dye and heavy metal from aqueous solution, Chemical Engineering Journal, 178 (2011) 60-68. 